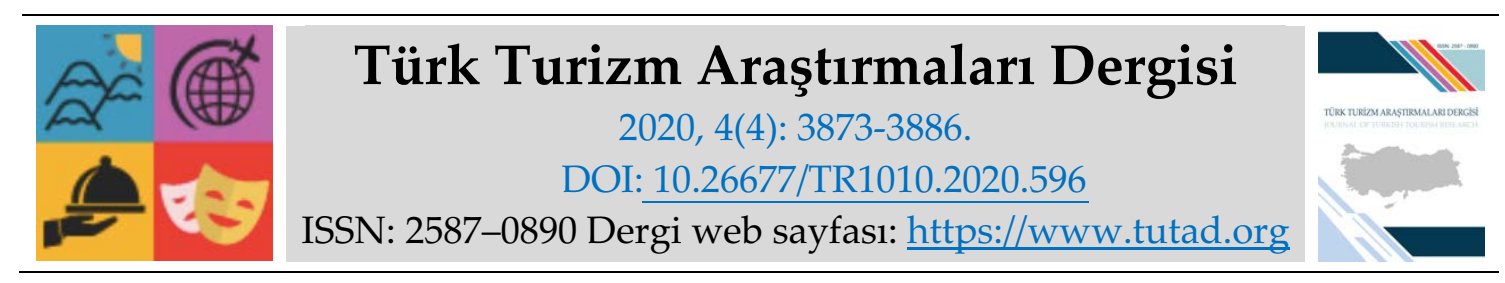

ARASTTIRMA MAKALESI

\title{
Eskişehir'in İlinde İnanç Turizmi Üzerine Bir Değerlendirme: Odunpazarı Örneği
}

Elif ŞENEL, Doktora Öğrencisi, Eskişehir Osmangazi Üniversitesi, Turizm Fakültesi, Eskişehir, e-mail: eozelmas@hotmail.com

ORCID: https://orcid.org/0000-0002-0374-6962

Öğr. Gör. İlker KILIÇ, Yozgat Bozok Üniversitesi, Akdağmadeni Meslek Yüksekokulu, Yozgat, e-posta: ilker.kilic@yobu.edu.tr

ORCID: https://orcid.org/0000-0003-0617-2260

Öz

Geçmişten günümüze gelen değerler, bazı uygulama ve inanışlar toplulukların ve toplum içerisinde yaşayan bireylerin manevi kültür değerlerini oluşturmaktadır. Türk geleneğinde asırlardır varlığını sürdüren bu değerler içerisinde türbeler oldukça önemli ve büyük bir paya sahiptir. Bu araştırmada Eskişehir'in Odunpazarı ilçesinde bulunan yatır ve türbelerin turistler özelinde Eskişehir turizmine yapmış olduğu katkı belirlenmeye çalışılmıştır. Araştırmanın evrenini Odunpazarı ilçesindeki türbeleri ziyaret eden tüm turistler oluşturmaktadır. Bu doğrultuda turistlerden veri toplamak amaciyla dağıtılan anketler sonucunda 350 kişiye ulaşılmıştır. Elde edilen bulgular kapsamında, gelen turistlerin büyük bir bölümü Eskişehir'i tekrar ziyaret etmek istemektedir. Ayrıca türbe ziyaretlerinden memnuniyet seviyelerinin oldukça yüksek olması, yaklaşık yarısının günübirlik ziyaret gerçekleştirmesi ve ziyaret esnasında Eskişehir ekonomisine alışveriş yaparak katkı sağlaması da araştırma bulguları arasında yer almaktadır.

Anahtar Kelimeler: Turizm, İnanç Turizmi, Odunpazarı.

Makale Gönderme Tarihi: 08.08.2020

Makale Kabul Tarihi: 10.10 .2020

\section{Önerilen Atıf:}

Şenel, E. ve Kılıç, İ. (2020). Eskişehir'in İlinde İnanç Turizmi Üzerine Bir Değerlendirme: Odunpazarı Örneği, Türk Turizm Araştırmaları Dergisi, 4(4): 3873-3886.

(C) 2020 Türk Turizm Araştırmaları Dergisi. 


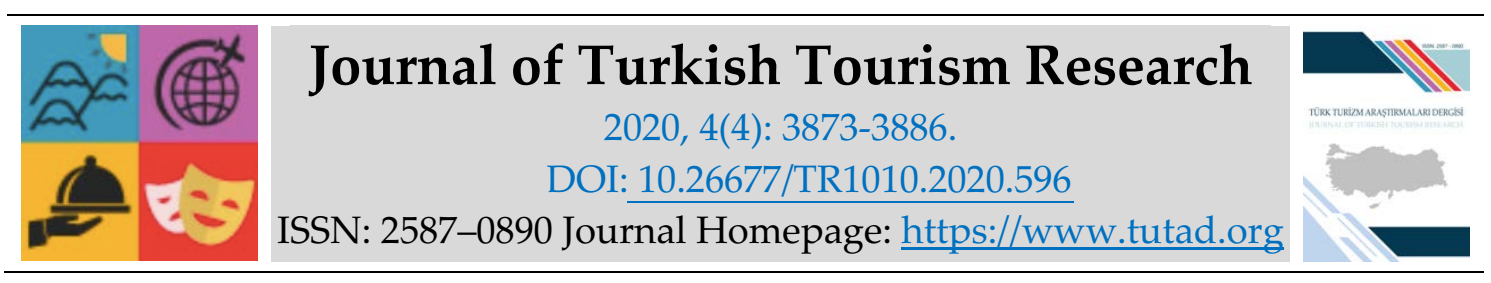

\title{
RESEARCH PAPER
}

\section{An Evaluation on Faith Tourism in Eskişehir Province: The Case of Odunpazarı}

Elif ŞENEL, Ph.D, Student, Eskişehir Osmangazi University, Faculty of Tourism, Eskişehir, email: eozelmas@hotmail.com ORCID: https://orcid.org/0000-0002-0374-6962

Lecturer İlker KILIÇ, Yozgat Bozok University, Akdağmadeni Vocational School, Yozgat, e-posta: ilker.kilic@yobu.edu.tr ORCID: https://orcid.org/0000-0003-0617-2260

\begin{abstract}
Values from the past to the present, some practices and beliefs constitute the spiritual-cultural values of communities and individuals in societies. Among these values, which have existed in the Turkish tradition for centuries, shrines have a very important share. In this study, it was aimed to determine the contribution of entombed saints and shrines located in Odunpazarı region to Eskisehir tourism. All the tourists visiting the shrines in the district of Odunpazarl constitute the population of the research. In this direction, the research survey was administered to 350 tourists to gather data. It was found with this study that most of the tourists who visit Eskisehir want to revisit the city. Besides, the fact that the level of satisfaction with their visit to the shrines is quite high, that about half of them make a daily visit and contribute to the economy of Eskisehir by shopping during their visit are also among the research findings.
\end{abstract}

Keywords: Tourism, Faith tourism, Odunpazarı.

Received: 08.08.2020

Accepted: 10.10 .2020

\section{Suggested Citation:}

Şenel, E. and Kılıç, İ. (2020). An Evaluation on Faith Tourism in Eskişehir Province: The Case of Odunpazari, Journal of Turkish Tourism Research, 4(4): 3873-3886.

(c) 2020 Türk Turizm Araştırmaları Dergisi. 


\section{Gíriş}

Gelenek ve göreneklerimiz içerisinde manevi açıdan üstünlük sahibi kişilere ait yatır ve türbelere ziyarette bulunma oldukça eskilere dayanmaktadır. Kültürümüz tarafından oldukça benimsenen ve yaygınlaşan bu ziyaretler bazı geleneksel uygulamaları da içermektedir. Bu uygulamalar inanışa göre kişinin dilek ve hacetlerinin gerçekleşmesi adına yapılan ilk adımı oluşturmaktadır. Ancak bu uygulamalar her yatır ve türbe için geçerli değildir. Sadece dua edilen ve namaz kılabileceğiniz bir ortama sahip yerlerde bulunmaktadır. Türbe ve yatır kelimeleri bazı kaynaklarda eş anlamlı olarak kullanılsa da bazı farklılıklar içermektedir. Türbe, bir tarikata mensup veya devlet içerisinde önde gelen kişilere için inşa ettirilen mezar üstü kapalı oluşumlardır. Yatırlar ise, yaşadığı zaman süresi içerisinde kişiler tarafından sevilen, sayılan, iyilikleri konuşulan, vefatlarından sonrada kerametlerine, mucizelerine ve iyiliklerinin devam ettiğine inanılan, ermiş olarak isimlendirilen kişilerin mezarları olarak kabul edilmektedir (Santur, 2001).

Türbe ve yatırlar, kişilerin içerisinde bulunan kabre ait kişinin manevi gücünden yaralanarak, çeşitli istek ve dileklerde bulunduğu ayrıca hastalıklar için de çare aradığı bir yer olma özelliğine sahiptir. Türbelere veya yatırlara adak adamak, kapının bir hacet için çalındığ 1 anlamına gelmektedir. Kapıyı çalan kişi adağın, yatırın kendisiyle Tanrı arasında bir çeşit aracılık vesile olacağını düşünür. Muradına erince adağını, yatıra aracılığı karşılığı verdiği sözü, yerine getirir. Vaat ettiği adak kurban ise bir hayvan kesilerek ihtiyaç sahiplerine dağıtılır, bir bağış ise türbeye veya bekçisine verir, bir eylem ise (Kur'an okuma, namaz kılma gibi) yerine getirilir (Özarslan, 2009). Tüm bu bilgiler ışığında türbe ziyaretlerinin turistik destinasyonlar için temel faktörler arasında olduğunu söylemek mümkündür.

İlgili alanyazın incelendiği ulusal ve uluslararası alanda inanç turizmi üzerine birçok araştırmaya rastlanmıştır. Söz konusu araştırmalar arasında Eşitti ve Kıngır (2015) göre inanç turizmi temel kalkınma unsurları arasında yer almaktadır. Eykay vd., (2015) Antakya bölgesinin inanç turizmi açısından yüksek potansiyele sahip olduğu ancak bölgede talebin yeterli seviyede karşılamaması sonucuna varılmıştır. Sezer ve Öztürk (2014) turistlerin türbe ziyaretlerinde temel amaçları arasında dua etmek ve isteklerinin karşılanması olduğu sonucuna varılmıştır. Albayrak vd., (2018) araştırmasına göre, inanç turizmi deneyimi zihinsel ilişki kurmak, yeni şeyler keşfetmek, ait olma hissiyatı, ruhsal ve duygusal olarak bağlanma hissi, rahatlamak ve etkileşim kurmak gibi çok yönlü boyutlardan oluşmaktadır. Uysal (2019) araştırmasına göre, Eskişehir halkı inanç turizmini turizmin kalkınması için bir fırsat olarak algılamaktadır.

Bu doğrultuda, araştırmada türbe ziyaretlerinin Eskişehir turizmine yapmış olduğu katkının ortaya konulması hedeflenmiştir. Araştırmanın literatüre iki şekilde katkı yapması beklenmektedir. Bunlardan ilki Eskişehir destinasyonunun inanç turizmi açısından ele alınacak olmasıdır. İkinci katkı ise Odunpazarı bölgesinde gerçekleşen inanç turizmi faaliyetlerinin Eskişehir turizmine hangi yönde katkı yapacağının açıklanacak olmasıdır.

\section{KAVRAMSAL ÇERÇEVE}

\section{İnanç Turizmi}

İnsanlık, varoluşundan itibaren kendini bir dine bağlı olma ihtiyacı duymuştur. Bu sebeple insanoğlunun var olmasından bu yana çok sayıda din ve inanç var olmuştur. Neticede kutsal yerler, gruplar ve kitleler halinde düzenli olarak ziyaret edilmiştir. Sonuç olarak alternatif turizm türleri arasında yer alan inanç turizmi kavramı doğmuştur (Güzel, 2010: 90). Turizmin ilk örnekleri arasında kabul edilen (Zamani-Farahani ve Eid, 2016) inanç turizmi, Dünya Turizm 
Örgütüne göre "Dua etmek, dini gereklilikleri yerine getirmek ve dini amaçlı toplantılara katılmak gibi aktiviteleri gerçekleştirmek amacıyla belirli bir dinin kutsal kabul edilen yerlerine yönelik gerçekleştirilen seyahatler" şeklinde ifade edilmektedir (Štefko, Királová ve Mudrík 2015).

Kültürel bir bakış açısıyla din ve turizm kavramı birbirlerini oldukça yakınlık göstermektedirler. $\mathrm{Bu}$ durumun temel sebebi, inanç turizminin çeşitli formlarından meydana gelen kültür ve geleneklerin özel cazibe merkezlerini oluşturmasıdır (Zhang vd., 2007: 98). Turizm, tarih boyunca inançları sebebiyle insanların kitleler halinde yer değiştirmesinden dolayı din kavramıyla yakından ilişkili olmuştur. Bu durumun başlıca sebebi insanların kutsal yerleri ziyaret etme isteğidir. Kutsal kabul edilen yapılar, dini bayramlar ve dini olaylar gibi unsurlar ziyaretçileri turizme yönlendirmekle kalmayıp aynı zamanda turistik davranışlarını da etkilemektedir (Henderson, 2003).

Herhangi bir yerin inanç turizmi açısından çekici unsura sahip olması için, dini önderlerin yaşamış oldukları, dini toplantılar gerçekleştirmiş oldukları veya vefat ettikten sonra mezarlarının bulundukları alanlar olarak ifade edilmektedir. Söz konusu alanlar arasında cami, kilise ve sinagog gibi inanç merkezlerinin yanında anıt mezarlar ve türbeler yer almaktadır (Özgen, 2012:253). İslam dini açısından değerlendirildiğinde kitleleri turizm sürükleyen temel faktör olan hac faaliyetleri doğrultusunda Mekke'nin ziyaret edilmesidir. Buna karşın daha küçük boyutta düşünüldüğünde cami, külliye ve türbe ziyaretleri de mikro seviyede değer yaratmaktadir.

\section{Türbelerin Tarihçesi}

\section{Hasan Hüsnü Dede Efendi}

Hasan Hüsnü Dede Efendi, 1246/1830-1 yılında Eskişehir'de doğmuştur. Babası Çürükoğlu Hacı Hafız Hüseyin Hüsnü Efendi, annesi Kerime Hanım'dır (Duru, 1952). Hasan Hüsnü Dede çocukluk yıllarının ardından ilk eğitimini alim ve Mevlevi şeyhi olan babası Hüseyin Hüsnü Efendiden almıştır. Akabinde medrese eğitimlerini bitirip icazetler aldıktan sonra müderris olmuştur ve Yenikapı Mevlevihanesi' ne giderek Osman Selahaddin Dede'ye teslim olmuştur. Osman Selahaddin Dede'nin manevi eğitimlerinden ve çile evresini tamamladıktan sonra Konya Çelebisi Muhammed Said Hemdem Çelebi'den Kadiri ve Mevlevi icazeti alarak Dede olmuştur (Albek, 1991, Küçük, 2003).

1865 yılında babası Hüseyin Hüsnü Efendi'nin vefat etmesi üzerine Eskişehir'e geri dönüş yapmıştır. Dönemin hükümetine başvuruda bulunarak, Gazi Mustafa Paşa'nın EskişehirOdunpazarı-Paşa Mahallesi'nde inşa ettirdiği Kurşunlu Camii bahçesinde bulunan yapının ve tekke odalarının, Mevleviliğe ait olduğunu ve şeyhliğinin de babasından kendisine geçtiğini bildirmiştir. Çok iyi bir at binicisi olan Hasan Hüsnü Dede hayır, hasenat ve gönül işlerine oldukça önem vermiş̧ir bu yönleriyle Fransız seyyah Clement Huart' in hatıralarına konu olmuştur. Hasan Hüsnü Dede zikir ve musiki çalışmalarının yanı sıra Mevlevi dergahında ki dede ve dervişlerin kazanç sağlayabilmeleri için mutlaka bir sanat dalıyla ilgilenmelerine önem vermiştir. Dergahtaki dervişler hem sosyal hayata hem de dergâha gelir sağlamak amacıyla bazı iş kollarında faaliyetlerde bulunmuşlardır. Eskişehir Mevlevihanesi' nde bu amaçlara yönelik üç adet fanila örme makinesi ve dört adet dokuma makinesi çalıştırılmıştır. Dergah içerisinde dokunan fanila ve çoraplar pazarcılar aracılığı ile şehirde satılarak, dergahın bütçesine ek gelir sağlanmıştır. Buradaki amaç ekonomiye katkı sağlamanın yanı sıra tekke ve zaviyelerin içerisinde bulunan maddi sıkıntılar ve işsiz halkın sığınma yeri olmasından dolayı dergahı koruma altına alma düşüncesidir. Hasan Hüsnü Dede mest giyer, ahşap bir asa taşır ve daimi 
surette temiz, sade ve Mevlevi dervişlerinin sema ayininde giydikleri geniş etekli beli kırmalı, kolsuz ve yakasız giysiden giymiştir. Mevlevi, Kadiri ve Melami şeyhi, alim ve fazıl bir kişi olan Hasan Hüsnü Dede Efendi, kırk üç yıl şeyhlik görevinde bulunmuş, yaşamını devam ettirdiği süre boyunca etrafındakileri güneş gibi aydınlatmış bir mürşit olarak kayıtlara geçmiştir. 28 Temmuz 1908 Salı günü fena aleminden beka alemine göç etmiştir (Duru, 1952).

\section{Ahu Mahmud Dede Türbesi}

Odunpazar'ında bulunan Ahu Mahmud Dede Kurşunlu Külliyesi yakınlarındaki evin içinde yer almaktadır. Ziyaretçileri türbenin bakımını da üstlenen, türbenin bulunduğu evde yaşayan kadın karşılamakta olup, türbe evin mutfağının ortasında bulunmaktadır. Ahu Mahmud Dede'nin iki odalı türbesinde yaşayan Hafize Gülserten, 60 yıldan bu yana türbede yattığını ve Ahu Mahmud Dede'ye hizmet ettiğini belirtmiş̧tir. Dede'ye ait olan yatırın Kurşunlu Camii Külliyesi ile yaşıt olduğu, yani Kanuni Sultan Süleyman döneminden bu yana var olduğu düşünülmektedir (www.yenisafak.com/).

\section{Kutup Şeyh Nusreddin Dede (Tezveren Dede) Türbesi}

Hakkında Pek fazla bilgi mevcut olmayan Kutup Şeyh Nusreddin Dede'nin Peygamber efendimizin soyundan geldiği ve mevlevi olduğuna dair rivayetler mevcuttur. Şeyh Nusrettin Dede yaklaşık olarak iki asır önce Kabe'de Beytullah'ın hizmetkarı olarak görev yapmakta iken bir dostunun ısrarı üzerine Eskişehir'e ziyarete gelmiştir. Buradaki misafirliği esnasında vefat eden Kutup Şeyh Nusreddin Dede'nin mübarek naşını yerinden kaldırmak istediklerinde bir türlü kıpırdatamamışlardır. O zaman kendisinin büyük bir veli olduğunu anlayıp vefatının gerçekleştiği bahçede bulunan evin misafir odasına Nusreddin Dede'yi defnederler. Ve orası Nusrettin Dede'nin türbesi haline gelir. Kendisini yüzyıllardır ziyaret edip, muradlarına tez nail olduklarına inanan insanlar zamanla kendisine Tezveren Dede olarak hitap etmeye başlamışlardır (Şeyh Nusrettin Dede, 2015).

\section{Şeyh Şehabettin Dede Türbesi}

Sühreverdiyye tarikatının kurucusu, Şeyh Şehabettin Dede 1145'de İran'ın Acem bölgesine bağlı Sühreverd kasabasında doğmuştur. Halife Nasır Lidinillah döneminde fütüvvet (ahilik) teşkilatlarının organize edilmesi çalışmalarında öncülük eden Şehabettin Dede, hilafet merkeziyle beylikler arasında bazı elçilik görevinde bulunmuştur. Kendisinden çok sayıda alim ders almış, sohbetlerine katılıp ondan feyiz almıştır. Öyle ki bu feyiz alanların sayısı binlerle ifade edilmektedir. Anadolu Selçukları döneminde Eskişehir'de Şeyh Şehabettin Sühreverdi adına bir türbe inşa edilmiştir. Türbe içerisinde Şeyh Şehabettin Dedeye ve oğluna ait olan mezarlar bulunmaktadır (Arslan, 2014).

\section{Şeyh Edebali Türbesi}

Osmanlı Devleti'nin manevi kurucusu olarak bilinen Şeyh Edebali' nin hayatı ve kişiliği hakkında bilgiler farklıdır. Ancak yaygın bilgilere göre Edebali' nin 1208 yılında Kırşehir ili Mucur ilçesi İnaç köyünde doğduğu kabul edilir ve her yıl anma günü düzenlenir (Hüsameddin, 1986). Osmanlı Devleti'nin kurucusu Osman Bey'in kayınpederi olan Şeyh Edebali, ilim sahibi ve ilmiyle amel eden bir bilge olduğu için halkın onun zaviyesini sık sık ziyaret ettiği rivayet edilmektedir. Aşıkpaşazade'de Osman Bey'in Şeyh Edebali'yi sıkça ziyaret ettiğini belirtmiştir. Edebali'yi büyük bir bilge olarak kabul eden Osman Bey, sohbetlerine katılır, misafiri olur, bazı 
konularda da görüşünü alıp, istişarelerde bulunmuştur (Taşköprüzade, 2007). Varlıklı, faal ve çevresi için örnek teşkil eden bir kişi olan Edebali Eskişehir yakınlarında İtburnu denilen köyde yaşamış, yaptırmış olduğu zaviyede öğrenciler yetiştirerek halkı aydınlatmıştır. Ayrıca Bilecik'te yaptırdığı dergahta Osman Gazi'yi bir çok kez misafir etmiştir (https://eskisehir.ktb.gov.tr/). Edebali'nin Eskişehir' de geçen yaşamının hatırasını en güzel şekilde anabilmek için Odunpazarı Kabristanı içinde bir makam türbe yapılmıştır. Avlu duvarları ile türbenin Sultan II. Abdülhamid döneminde onarım gördüğü tahmin edilmektedir. 1326' da 125 yaşlarında Bilecik'te vefat etmiş, dergâhının yanında gömülmüştür (Taşköprüzade, 2007).

\section{Şeyh Mehmed Sadık Dede Efendi}

Eskişehir'de yetişen gönül erlerinden biri de Halveti-Şabaniyye şeyhlerinden Şeyh Mehmed Sadık Dede efendidir. Şeyh Mehmed Sâdık Efendi, Eskişehir'de 1865 yılında doğmuştur (Özçelik, 2013). Söğütlü Hacı Osman ve Çaltılı İsmail Hakkı Efendinin kısa bir süre postnişin olmasından sonra post İsmail Efendi'den Eskişehir'li Mehmed Sadık Dede Efendi'ye geçmiştir. Eskişehir Belediye reisi olarak da görev yaptığı da bilinen Mehmed Sadık Efendi halk arasında "Deli Sadık" lakabıyla tanınmıştır. Meclis-i Meşayıh tarafından görevlendirilen, tekkelerin seddine kadar (1925) devletten maaş olan son şeyh olarak bilinen Sadık Dede efendinin Eskişehir'de bulunan dergahı o dönemde, Sultan Hamid tarafından beş altın lira maaşa bağlanmıştır (Dumlu, 2001: 116). Sadık Dede Efendi tasavvuf olgusu içerisinde faziletli ve kerem sahibi yapısı ile tanınmıştır. Mehmet Sadık Dede Efendi 1922 senesinde vuslat etmiş ve Odunpazarı mezarlığına defnedilmiştir (Yalsızuçanlar, 2012).

\section{ODUNPAZARI BÖLGESINDEKI TÜRBELERIN UYDU GÖRÜNTÜSÜ VE HARITA ÜZERINDEKI GÖSTERIMI}
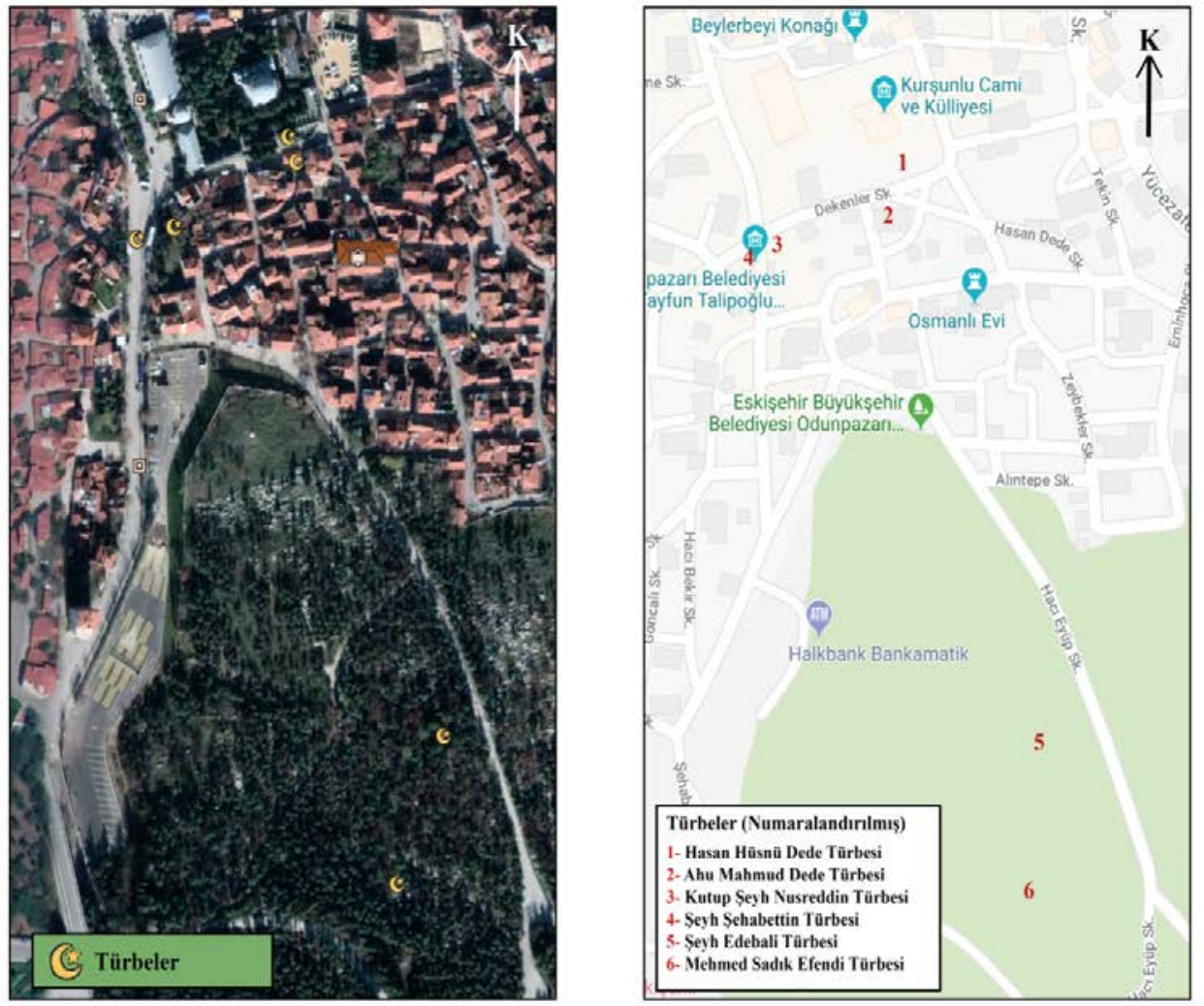

Şekil 1. Odunpazarı Bölgesindeki Türbeler 


\section{YÖNTEM}

\section{Araştırmanın Amacı}

Araştırmada, Türkiye'nin önde gelen yerli turistik destinasyonları arasında gösterilen Eskişehir ilinin Odunpazarı bölgesinde bulunun türbelerin Eskişehir turizmine yapmış olduğu katkının belirlenmesi amaçlanmıştır. Bu doğrultuda ilk olarak Odunpazarı bölgesinde bulunan ve Şekil 1'de yerleri ayrıntılı olarak gösterilen altı türbe hakkında detaylı bilgi verilmiştir. İkinci olarak söz konusu bölgeye gelen turistlerin türbe ziyaretleri hakkındaki fikirleri belirlenmeye çalışılmıştır. Bu kapsamda elde edilen bulgular neticesinde türbe ziyaretlerinin Eskişehir turizmine olan katkısı belirlenmeye çalışılmıştır.

\section{Ölçme Araçları}

Eskişehir Odunpazarı bölgesindeki turistlerin türbe ziyaretlerindeki amaç, tekrar ziyarete etkisi ve memnuniyet düzeyleri Sezer ve Öztürk, (2014) araştırmasında kullanılan ifadelerin uyarlanması sonucu elde edilmiştir. Türbelere geliş sayısı, konaklama gece sayısı ve ziyaret sırası alışveriş yaptıklarını ölçen ifadeler araştırmacılar ve alanında uzman araştırmacıların fikirleri alınarak oluşturulmuştur. Veri toplamak amacıyla oluşturulan anket iki bölümden oluşmaktadır. İlk bölümde türbe ziyaretinde bulunan katılımcıların çeşitli fikirlerinin belirlendiği 6 adet ifade yer alırken ikinci bölümde katılımcıların demografik özellikleri yer almaktadır.

\section{Araştırmanın Evren ve Örneklemi}

Türbe ve yatırlara olan inanış, ilgi ve merak din turizmi adı altında seyahatler oluşmasına yol açmaktadır. Türkiye'nin dört bir yanından bireyler yatırlarda medfun zatlara ulaşabilmek için yer değiştirmektedir ve bu esnada ev sahibi şehirde bulunan halk ile etkileşim içerisine girmektedir. Manevi açıdan üstünlükleri bulunan bu zatlar Anadolu'nun her bir köşesine yayılmış bulunmaktadır. Eskişehir'de bu zatlara ev sahipliği yapan illerimizden bir tanesidir. Özellikle Eskişehir için oldukça önemli bir destinasyon olan Odunpazarı ilçesi yatır ve türbeler açısından oldukça zengindir. Buna göre, araştırmanın evrenini Eskişehir Odunpazarı'nda bulunan altı türbeyi ziyaret eden tüm turistler oluşturmaktadır.

2019 yılında mevcut türbeleri yaklaşık olarak kaç kişinin ziyaret ettiği bilinmediğinden dolayı araştırmanın evrenini tam olarak ortaya koymak mümkün değildir. Evrenin tamamına ulaşmanın zaman, ulaşılabilirlik ve maliyet açısından yetersiz olmasından dolayı temsil kabiliyeti olarak 384 kişiye ulaşılması planlanmıştır (Altunışık vd., 2017:144). Araştırmada örnekleme tekniği olarak olasılığa dayalı olmayan kolayda örnekleme yöntemi izlenmiştir. Örneklem olarak belirlenen 384 kişiye ulaşabilmek için 420 adet anket dağıtılmıştır. Ancak söz konusu anketler arasında 400 adet geri dönüş olmuş bunlardan 50 tanesi analize değer bulunmadığından dolayı 350 adet veri ile araştırmaya devam edilmiştir.

\section{BULGULAR}

Araştırmanın bulgular kısmında ilk olarak katılımcıların demografik özelliklerine yer verilmiştir. İkinci kısımda ise katılımcıların türbe ziyaretleri hakkındaki fikirleri ve Eskişehir turizmine yapmış oldukları katkının belirlenmesi amacıyla sorulan altı adet ifadenin frekans yüzdelikleri alınarak elde edilen bulgular ayrıntılı olarak ele alınmıştır.

Katılımcların demografik özellikleri Tablo 1'de ayrıntılı olarak yer almaktadır. Söz konusu ifadelere bakıldığında katılımcıların büyük bir çoğunluğunun $(\% 64,3)$ kadın olduğu 
görülmektedir. Bu durum türbe ziyaretlerini kadınların erkeklere göre daha fazla tercih ettiğin bir göstergesi olabilir. Katılımcılar yaş değişkeni kapsamında ele alındığın ise yaklaşık olarak (\%65) oranında bir kısmın 36-55 yaş aralığında olduğu görülmektedir. Ayrıca 18-25 yaş aralığı sadece (\%4'lük) bir orana sahiptir. Bu bulgulara göre, türbe ziyaretlerini gerçekleştiren turist profilinin daha çok orta yaş ve üzerinde olduğu ifade edilebilir. Eğitim durumu açısından katılımcılar değerlendirildiğinde yaklaşık olarak (\%40) oranı ile ilk sırada önlisans-lisans mezunu kişiler yer almaktadır. Son olarak araştırmaya katılan turistlerin gelir durumuna bakıldığında (\%65'e) yakın bir kısmı 2000-3999 gelir bandı arasında yer almaktadır. Elde edilen bu bulgu türbe ziyareti gerçekleştiren turistlerin büyük bir kısmının orta gelir düzeyinde olduğunu göstermektedir.

Katılımcılara ilk olarak "Türbelere yapmış olduğunuz ziyaretlerden memnun kaldınız mı?" ifadesi yöneltilmiştir. Elde edilen bulgular Tablo 2' de ayrıntılı olarak yer almaktadır. Söz konusu bulgulara göre turistlerin çok büyük bir kısmı $(86,9)$ ziyaretlerinde memnun kalmıştır. Memnun olmayan kısım $(\% 1,1)$ ile oldukça düşük seviyededir. Ayrıca hiç memnun olmayan hiçbir turist yoktur. Bu durumun türbe ziyaretlerinin inanç boyutuyla da ilgili olduğunu akıllara getirmektedir.

Tablo 1: Katılımcıların Demografik Özellikleri

\begin{tabular}{llcc}
\hline & Değişken & (n) & \% \\
\hline Cinsiyet & Erkek & 125 & 35,7 \\
& Kadın & 225 & 64,3 \\
\hline Yaş & $18-25$ & 14 & 4,0 \\
& $26-35$ & 52 & 14,9 \\
& $36-45$ & 114 & 32,6 \\
& $46-55$ & 109 & 31,1 \\
& 56 ve üzeri & 61 & 17,4 \\
\hline Eğitim & İlkögrretim & 47 & 13,4 \\
& Lise & 132 & 37,7 \\
& Ön lisans-Lisans & 144 & 41,1 \\
& Lisansüstü & 27 & 7,7 \\
\hline Gelir & 1000 TL'den az & 21 & 6,0 \\
& $1000-1999$ & 34 & 9,7 \\
& 2000-2999 & 117 & 33,4 \\
& 3000-3999 & 108 & 30,9 \\
& $4000-5000$ & 57 & 16,3 \\
& 5000 TL'den fazla & 13 & 3,7 \\
\hline Total & & 350 & 100 \\
\hline
\end{tabular}

Tablo 2. Katılımcıların Türbe Ziyaretlerinden Memnuniyet Seviyelerinin Yüzdelik Dağılımı.

\begin{tabular}{lcc}
\hline & (n) & (\%) \\
\hline Çok Memnunum & 162 & 46,3 \\
\hline Memnunum & 142 & 40,6 \\
\hline Kismen Memnunum & 42 & 12,0 \\
\hline Memnun Değilim & 4 & 1,1 \\
\hline Hiç Memnun Değilim & - & - \\
\hline Toplam & 350 & 100 \\
\hline
\end{tabular}


Katılımcllara yöneltilen ikinci ifade ise "Türbelere bir daha gelmeyi düşünüyor musunuz?" sorusudur. İfadeye verilen yanitlar Tablo 3'te yer almaktadır. Elde edilen bulgulara göre yaklaşık olarak (\%72) bir kısım tekrardan türbeleri dolayısıyla Eskişehir'i ziyaret etmeyi düşünmektedir. Buna karşın $(\% 27,1)$ çeşitli sebeplerden dolayı tekrar ziyaret etmeyi düşünmemektedir.

Tablo 3: Katılımcıların Türbeleri Tekrar Ziyaret Etme İsteklerinin Yüzdelik Dağılımı.

\begin{tabular}{lcc}
\hline & (n) & (\%) \\
\hline Evet & 255 & 72,9 \\
\hline Hayir & 95 & 27,1 \\
\hline Toplam & 350 & 100 \\
\hline
\end{tabular}

Araştırma sorulara arasında yer alan bir diğer ifade "Türbelere geliş amacınız nedir?" ifadesidir. Söz konusu ifadeye verilen yanıtlar Tablo 4'te ayrıntılı olarak yer almaktadır. Bulgular arasında en yüksek değere $(\% 27,1)$ sahip olan huzur bulmak ifadesini (\%26) ile dua etmek izlemektedir. Bulgulara göre gelen turistlerin büyük bir bölümünün ziyaretteki temel amaçlarının içsel huzuru yakalamak ve yakarış olduğu anlaşılmaktadır. Ek olarak manevi sıkıntıdan kurtulmak ve namaz kılmak gibi amaçların da toplamda (\%35'e) yakın bir değerde olduğu ortaya konulmuştur.

Tablo 4: Katılımcıların Türbelere Geliş Amaçlarının Yüzdelik Dağılımı.

\begin{tabular}{lcc}
\hline & (n) & (\%) \\
\hline Dua Etmek & 91 & 26,0 \\
\hline Huzur Bulmak & 95 & 27,1 \\
\hline Manevi Sıkıntıyı Gidermek & 65 & 18,6 \\
\hline Namaz Kılmak & 55 & 15,7 \\
\hline Diğer & 44 & 12,6 \\
\hline Toplam & 350 & 100 \\
\hline
\end{tabular}

“Türbelere kaçıncı gelişiniz?” ifadesine verilen yanıtlar Tablo 5'te ayrıntılı olarak yer almaktadır. Katılımcılar yüksek oranda ilk $(\% 32,6)$ veya ikinci $(\% 28)$ olarak ziyaretleri gerçekleştirmişlerdir. Elde edilen bulgular arasında en dikkat çekici sonuçlar arasında yaklaşık olarak (\%70) ile turistlerin türbeleri tekrar ziyaret etmesidir. Bu durum türbe ziyareti gerçekleştiren turistlerin inançları gereği düzenli olarak ziyaret ettiklerinin bir göstergesi olabilir.

Tablo 5. Katılımcıların Türbeleri Kaçıncı Kez Ziyaret Ettiklerinin Yüzdelik Dağılımı

\begin{tabular}{lcc}
\hline & (n) & (\%) \\
\hline İlk & 114 & 32,6 \\
\hline İkinci & 98 & 28,0 \\
\hline Üçüncü & 68 & 19,4 \\
\hline Dört ve Üzeri & 70 & 20,0 \\
\hline Toplam & 350 & 100 \\
\hline
\end{tabular}


Araştırma soruları arasında yer alan "Türbe ziyaretiniz sırasında Eskişehir'deki konaklama gece sayınızı belirtiniz?" ifadesine verilen yanitlar Tablo 6'da ayrıntılı olarak yer almaktadır. Elde edilen bulgular arasında en dikkat çekici olan $(\% 49,7)$ ile gelen turistlerin büyük bir kısmının günübirlik olarak Eskişehir'e gelmiş olmasıdır. Bu durum Eskişehir turizminin temel sorunları arasında gösterilebilir. Ek olarak $(\% 26,6)$ oranındaki turistlerin geceleme sayısı 1'dir. Bu da Eskişehir'e gelen turistlerin genel itibariyle ya günübirlik ya da 1 gece konakladığının bir göstergesi olarak karşımıza çıkmaktadır.

Tablo 6: Katılımcıların Türbe Ziyaretleri Esnasında Eskişehir İlindeki Konaklama Sayılarının Yüzdelik Dağılımı

\begin{tabular}{lcc}
\hline & (n) & (\%) \\
\hline Günübirlik & 174 & 49,7 \\
\hline 1 Gece & 93 & 26,6 \\
\hline 2 gece & 41 & 11,7 \\
\hline 3 gece & 20 & 5,7 \\
\hline 4 gece & 15 & 4,3 \\
\hline 5 ve üzeri & 7 & 2,0 \\
\hline Toplam & 350 & 100 \\
\hline
\end{tabular}

Araştırmanın son ifadesi olan "Türbe ziyaretleri öncesi veya sonrasında Eskişehir'den alışveriş yaptınız mı?" verilen yanıtlar Tablo 7'de yer almaktadır. Elde edilen bulgular Eskişehir Odunpazarı bölgesinde bulunan türbeleri ziyaret eden turistlerin çok büyük bir kısmının $(94,6)$ alışveriş yaptığını göstermektedir. Bu bulgu türbe ziyareti gerçekleştiren turistlerin Eskişehir ekonomisine katkı yaptığını ortaya koymaktadır.

Tablo 7: Katılımcıların Türbe Ziyaretleri Esnasında Eskişehir'de Alışveriş Yapıp Yapmadıklarının Yüzdelik Dağılımı

\begin{tabular}{lcc}
\hline & (n) & (\%) \\
\hline Evet & 331 & 94,6 \\
\hline Hayır & 19 & 5,4 \\
\hline Toplam & 350 & 100 \\
\hline
\end{tabular}

\section{TARTIŞMA ve SONUÇ}

Eskişehir, Sakarya ve onu besleyen akarsuların meydana getirdiği ovalarıyla, birçok medeniyete ev sahipliği yapan ve bu medeniyetlere ait kültür mirasını coğrafyasında barındıran bir şehrimizdir. Özellikle Oğuz boylarının Anadolu'yu vatan tutmasıyla birlikte Eskişehir coğrafyasına gelen erenler burada zaviyeler kurarak şehrin "bilgeler diyarı" olarak adlandırılmasına vesile olmuşlardır. Eskişehir, termal ve kültür turizmi başta olmak üzere birçok alternatif turizm türünde oldukça önemli bir potansiyeli oluşturmakla birlikte manevi coğrafyası da oldukça kuvvetli olan bir şehrimizdir. Özellikle kendi halkı tarafından yoğun bir şekilde ziyaret edilen Odunpazarı bölgesi ayrıca il dışından da ziyaretçileri kendisine çekmektedir. İnanç turizmi çatısı altında değerlendirilebilecek olan bu ziyaretlerin özellikle turistlerde oluşturduğu etkilerin öğrenilmesi, şehirde var olan inanç turizminin sürdürülebilirliği ve gelişimi açısından oldukça önemlidir.

Günümüzde bireylerin özellikle diğer turizm türlerinden farklı olarak inanç turizmine yöneldiği düşünüldüğünde ise sahip olunan manevi değerlerin turizm hareketliliği içerisindeki payının ne 
kadar büyük olduğu görülmektedir. Eskişehir'de inanç turizmini konu alan bu araştırmada literatür taraması yapıldıktan sonra türbeleri ziyaret eden turistlere anket çalışması yapılmıştır. Yapılan analizler sonucunda ilk olarak katılımcıların gerçekleştirdikleri türbe ziyaretlerinden memnun kaldıkları görülmüştür. Eskişehir Odunpazarı gerek tarihi gerekse türbeleri ile oldukça dikkat çeken ve turistlerin uğramadan dönmedikleri bir bölgeyi oluşturmaktadır. Özellikle türbelerin birbirlerine olan yakınlığından ötürü birkaç gün içerisinde defalarca ziyaret edilmektedir. Çekim gücü bu kadar yüksek olan türbeleri ziyaret eden turistlerde oluşan memnuniyet, türbelerin bir bütün halinde yapım, onarım ve bakım faaliyetleri açısından yeterliliğini gösterirken, genel görünüm, temizlik ve erişilebilirliği açısından da iyi durumda olduğunu ve katılımcıların türbelerde bulunma amaçlarının temelinde inanç faktörünün bulunduğunu kanttlar niteliktir. Bu noktada Eskişehir Odunpazarı bölgesine ait türbelerin restorasyonun ve bakımının düzenli olarak yapılması bilge şahsiyetlerin ve geride bıraktıkları değerlerin gelecek nesillere aktarımının sağlanması adına oldukça önemli bir adımı oluşturmaktadır. Ayrıca memnuniyet seviyesinin yükselmesi ve bu türbelere ait olumlu düşüncelerin oluşmasıyla birlikte turistlerin çoğunluğunun bu mekanların mutlaka görülmesi kanaatinde olacağı ve insanlara buralara ziyaretler gerçekleştirmeleri konusunda tavsiyeler de bulunacakları düşünülmektedir.

Katılımcıların tekrar ziyaret etme eğiliminde belirlenen yüzde ise Eskişehir'deki türbelere ait bilgi, inanç, his ve izlenimlerin oldukça fazla olduğunun ve Eskişehir'e ait manevi destinasyon imajının tekrar ziyaret etme eğilimi üzerinde etkili olduğunun göstergesi durumundadır. Turistlerin türbeleri tekrar ziyaret etme oranlarının oldukça yüksek olması, değer yargılarımızdan kaynaklı olarak türbede yatan zata karşı vefa borcu ve saygı ifadesi niyetiyle birden fazla olmak üzere tekrarlandığını göstermekte ve manevi doyumun bir ziyaretle gerçekleşebileceği gibi birden fazla ziyaretle de oluşabileceğinin göstergesidir. Ayrıca türbelerin birden fazla olarak ziyaret edilmesi inanç ve geleneklere ait vazifelerin sürekliliğinin sağlanması adına da gerçekleştirildiğini kanıtlar durumdadır. Özellikle türbelere yapılan ziyaretlerde bireylerin dini inançlarının bir gereği olarak kutsal kabul ettikleri mekanlara belli aralıklar ile ziyaret gerçekleştirdikleri ve ölümden sonraki hayatta bu ziyaretlerin insanlara faydalarının olacağına dair inanışlarında bulunması tekrar ziyaret etme eğilimi nedenleri arasında bulunmaktadır. Ayrıca türbelerin oldukça ulaşılabilir ve erişime kolay yerlerde olması da turistlerin türbelere daha kolay ve tekrarlanmak suretiyle ziyaret edebilmesine imkân tanır niteliktedir.

Türbe ziyaretleri sırasında Eskiş̧ehir'deki konaklama gece sayısına bakıldığında ise, gelen turistlerin büyük bir çoğunluğunun günübirlik denilecek bir profile sahip olduğunu göstermektedir. Bu durumda çözülmesi gereken bir konu haline gelen turistlerin kalış süresini uzatabilme problemini gözler önüne sermektedir. Nitekim konaklama sayısının uzatılması adına yapılabilecek birçok uygulama söz konusudur ancak Eskişehir'e inanç turizmi için gelen turistlerin şehirde bulunan alternatif turizm türleri hakkında bilgilendirilmelerinin sağlanması, çevre bölgeleri tanıcı faaliyetler, konaklama ve yeme içme gereksinimlerini karşılayabilmeleri için gerekli olan tesislerin kurulması, yöreyi temsil eden hediyelik eşya dükkanlarının çeşitliliği, sosyal ve kültürel etkinliklere ağırlık verilmesi gelen turistlerin şehirde bulunma sürelerini uzatacak bir etki yaratırken konaklama sürelerini uzatıcı bir etki de gösterebilir. Bu noktada işletmelerin ve yerel yönetimlerin bir arada organize olarak hareket etmeleri, turistlerin inanç turizmi kapsamında gerçekleştirdikleri ziyaretler esnasında yaşanan eksiklerin belirlenmesi ve bu eksikliklere göre bölgeye hizmetler oluşturması geceleme sayısının arttırılması adına yapılabilecek önemli adımlar arasındadır. Eskişehir Odunpazarı bölgesinde bulunan turistik tesis ve yatak sayısının arttırılması, mevcut tesislerin hizmet kalitelerinin ve konforlarının tekrar gözden geçirilmesi de konaklama sürelerinin artışında katkı sağlayacağı düşünülmektedir. Ve 
özellikle bölgede bulunan inanç turizmi potansiyeline yönelik tanitıcı, bilgilendirici reklam, tanıtım ve broşür gibi materyallerin hazırlanması bölgede bulunan diğer türbeleri bilmeyenleri o alanlara yönlendirecek ve gerçekleşen tanıtımlar sayesinde kalış sürelerinde artış meydana gelmeye başlayacaktır. Dolayısıyla inanç turizmi adına bu yatırımların yapılması, planlanması bölgenin taşıma kapasitesinin belirlenmesi, standartların saptanması ve doğru yönlendirilmeler ile birlikte Eskişehir Odunpazarı bölgesinin inanç turizminden istenilen payı alması ve bölgedeki konaklama gece sayısının artması mümkün olabilecektir.

Eskişehir'de Odunpazarı bölgesinde bulunan türbeleri ziyaret eden turistlerin çok büyük bir kısmının alışveriş yaptığı sonucuna ulaşılmakla birlikte özellikle inanç turizmi amacıyla gerçekleştirilen ziyaretlerin gidilen bölge halkını ekonomik ve sosyal açıdan olumlu anlamda etkilediği görülmektedir. Öncelikle türbeler etrafında yaşayan yerel halkın ve esnafın türbe ziyaretleri gerçekleştiren turistlere karşı geliştirdiği düşünceler, tepkiler ve bunlara yönelik algılar, inanç ziyaretlerinin devamlılığı, ziyaret miktarının artması ve bu ziyaretlerin rahat bir şekilde gerçekleştirilebilmesi açısından oldukça önemlidir. İki tarafında kazandığı bu turist hareketliliğinin ilerlemesi durumunda ise türbelerin çevresinde sosyal ve ekonomik hareketlerde hız kazanmaya başlayacaktır. Turistler ve halk arasında meydana gelen olumlu diyaloglar, hoşgörü ortamının oluşması ve empati yapabilme yeteneğinin bulunması, turistlerin memnuniyet seviyelerini arttırırken bölge de gerçekleştirilen alışverişler sayesinde hem bölgesel hem de şehir olarak ekonomik yönlü bir katkı meydana gelecektir. Özellikle yöreye ait ve orayı temsil eden hediyelik eşyaların imal edilmesi ve pazara sunulması da Eskişehir Odunpazarı' na inanç turizmi kapsamında gelen turistlerin yaşadıkları yere dönerken yanlarında götürebilecekleri Eskişehir'i ve sahip olduğu manevi değerleri sembolize eden bir ürün olarak hem ekonomik hem de tanıtım amaçlı katkı sağlayacaktır. Ayrıca bu noktada yerel esnafın kalkınması beraberinde halka istihdam ortamı yaratacak ayrıca Odunpazarı bölgesi inanç turizmi için bir cazibe merkezi haline gelirken tatmin düzeyleri artan turistlerin uzun vadeli konaklamasından doğan uzun vadeli ekonomik gelişmeler ortaya çıkmaya başlayacaktır. Ayrıca inanç turizminin belirli bir ayının veya mevsiminin olmaması yılın on iki ayına da yayılabilecek bir özellikte olması ziyaret edilen bölge halkına, konaklama ve diğer bütün işletmelere ekonomik katkı sağlayacağı gibi yerel halka da uzun vadeli bir gelir oluşturacaktır.

Sonuç olarak Eskişehir Odunpazarı inanç turizmi açısından oldukça yüksek bir potansiyele sahip olan bir bölgedir. Bölgede birçok türbenin bulunması ve Odunpazarı'nın kendine ait mistik bir havasının olması turistleri cezbeden ve turist sayısını günden güne artıran bir yapı oluşturmaktadır. Bu noktada alanda inanç turizmine ait bir envanter çalışması, inanç turizmi potansiyelinin belirlenmesi için çalışmalar gerçekleştirmek, şehre ait inanç turizmi alt yapısının doğru tanımak ve bilgilendirilmeler yapmak oldukça önem taşımaktadır. Çünkü bölgeye ait inanç turizminin bugünkü durumunun tespiti, gelecekteki potansiyelini ortaya koymak ve gelecekte nerelere gelebileceğinin daha net anlaşılması ve yapılacak olan yatırımların şekillendirilmesi, inanç turizmi sektöründeki açıkların ve eksiklerin belirlenmesi ve yanlış adımlar atılmaması adına öncelik taşımaktadır. Özellikle Eskişehir Odunpazarı bölgesinin inanç turizmi ile ilgili mevcut durumu, turistlerin demografik özellikleri, ihtiyaç ve beklentileri tespit edilmelidir ve tüm bu veriler ışığında hareket edilmesi gerekmektedir.

\section{KAYNAKÇA}

Albayrak, T., Herstein, R., Caber, M., Drori, N., Bideci, M., and Berger, R. (2018). Exploring religious tourist experiences in Jerusalem: The intersection of Abrahamic religions. Tourism Management, 69, 285-296.

Albek, S. (1991). Dorlion'dan Eskişehir'e. Anadolu Üniversitesi Basımevi, Eskişehir, S.268. 
Altunışık, R. Coşkun, R. Bayraktaroğlu, S. ve Yıldırım, E. (2017). Sosyal Bilimlerde Araştırma Yöntemleri: SPSS Uygulamalı. Sakarya Yayıncılık, 9. Baskı. Sakarya.

Arslan, N. (2014). Eskişehir Bilgeleri, Eskişehir 2013 Türk Dünyası Kültür Başkenti Ajansı, Erdoğan, A. (Ed.), Semih Ofset, Ss. 77-80, Eskişehir.

Dumlu, M. (2010). Batmayan Güneş Devam Eden Gölgeler. İstanbul: İrfan Yayıncılık.

Duru, M. C. (1952). Tarihi Simalardan Mevlevi. Kader Basımevi, İstanbul, s.164.

Eskişehir İl Kültür ve Turizm Müdürlüğü, (2019). Https://Eskisehir.Ktb.Gov.Tr/Tr-150034/SeyhEdebali-1206---1326.Html, Erişim Tarihi: [12.08.2019].

Eşitti, B., ve Kıngır, S. (2015). Konya ili örneğinde kalkınma ve inanç turizmi. Bartın Üniversitesi İ BF Dergisi, 6(12), 175-190.

Eykay, İ., Dalgın, T., ve Çeken, H. (2015). İnanç Turizmi Potansiyeli Açısından Antakya'nın Değerlendirilmesi. Journal of Life Economics, 2(2), 59-74.

Güzel, Ö. (2010). Turistik Ürün Çeşitlendirmesi Kapsamında Yeni Bir Dinamik: İnanç Turizmi. Süleyman Demirel Üniversitesi Vizyoner Dergisi, 2(2), 87-100.

Henderson, J. C. (2003). Managing tourism and Islam in peninsular Malaysia. Tourism Management, 24(4), 447-456.

Hüsameddin, A. H. (1986). Amasya Tarihi III. Amasya Belediyesi Kültür Yayınları, S. 206, Ankara.

Küçük, S. (2003). Mevlevilerin Son Yüzyılı. Simurg Yayınları, İstanbul, S.220.

Özarslan, M. (2009). Üsküdar'da Yatır ve Ziyaret Yerleri. Motif Akademi Halkbilimi Dergisi, 2(3-4), 300-308.

Özçelik, M. (2013). Eskişehir'in Mânevî Coğrafyası. Somuncu Baba Dergisi, 149, 75-76.

Özgen, N. (2012). Siirt'in İnanç Turizmi Mekânları: Ziyaret (Veysel Karani) ve Tillo (Aydınlar) Örnekleri. Eastern Geographical Review, 17(27), 251-272.

Santur, A. (2001). Türbe ve Yatırlar Etrafındaki İnanışların Atatürk Devrimleri ve Halk Hekimliği Çerçevesinde Değerlendirilmesi. I. Uluslararası Atatürk ve Türk Halk Kültürü Sempozyumu Bildirileri, Ankara, Kültür Bakanlığı Yay., ss. 241- 242.

Sezer, İ., ve Öztürk, B. (2014). İnanç Turizmi Kapsamında Yapılan Türbe Ziyaretlerinin, Ziyaretçilerin Bakış Açısıyla Değerlendirilmesi: Şeyh Kerameddin Türbesi Örneği (Boztekke Köyü/Giresun). International Journal of Social And Economic Sciences, 4(2), 45-50.

Štefko, R., Királová, A., and Mudrík, M. (2015). Strategic marketing communication in pilgrimage tourism. Procedia-Social and Behavioral Sciences, 175(12), 423-430.

Şeyh Nusrettin Dede, (2015). Https://Www.Facebook.Com/Pages/Seyh-Nusrettin-TezverenDede-Turbesi/265884396793311, Erişim Tarihi: [15.08.2016].

Taşköprüzade, İ. E. A. (2007). Osmanlı Bilginleri-Eş-Şakaiku'n-Nu'maniyye Fi-Ulemai'dDevleti'l-Osmaniyye. (Çev. Muharrem Tan), İz Yayıncllık, İstanbul.

Uysal, D. (2019). A Research on the Investigation of the Attitudes of the Local People in Eskişehir Towards Faith Tourism. Uluslararası Güncel Turizm Araştırmaları Dergisi, 3(1), 28-42.

Yalsızuçanlar, S. (2012). Hakikat Sırrının Dili: Mehmed Sadık Efendi. I. Uluslararası Şeyh Şa’BânI Velî Sempozyumu, Kastamonu Üniversitesi, Ss. 193. 
Yeni Şafak, (2008). Https://Www.Yenisafak.Com/Yenisafakpazar/Yatirdan-Degil-DirilerdenKorkuyorum-123234, Erişim Tarihi: [16.08.2019].

Zamani-Farahani, H., and Eid, R. (2016). Muslim World: A Study of Tourism and Pilgrimage Among OIC Member States. Tourism Management Perspectives, 19, 144-149.

Zhang, M., Huang, L., Wang, J. H., Liu, J., Jie, Y. G., and Lai, X. (2007). Religious tourism and cultural pilgrimage: A Chinese perspective. Religious tourism and pilgrimage management. An International Perspective, 98-112. 